\title{
COMPETITIVENESS OF SLOVAK ENTERPRISES IN CENTRAL AND EASTERN EUROPEAN REGION
}

\author{
Milota Vetráková, Lukáš Smerek
}

\section{Introduction}

Many changes occurred in the management of the economy in Slovakia caused by the transition from a centrally planned economy to a market economy at the turn of the 1980 s and 1990s. The process of globalization into Slovak economic conditions was limited due to initial alertness. While the governments of Poland, Hungary and the Czech Republic presented themselves as pro-reform, the Slovak government preferred Slovak privatizers (Kosír, 2016). Nevertheless, the retail chain Billa entered Slovak market in 1990, followed by automobile giant Volkswagen in 1991, American retail chain Kmart in 1992, which took over the department stores Prior. Because of the reforms implemented, Slovakia gains confidence from foreign investors. Significant foreign capital inflows into the emerging business environment of the Slovak economy, such as Heineken, Coca-Cola, McDonald's and others. A courtesy of Slovak government has also become reprivatisation of VSŽ Košice, which became part of the U.S. Steel, based in Pittsburgh in the USA.

The operation of multinational companies in other countries is a natural consequence of globalization, which was pioneered in the 1960s by the USA. Establishment of multinational companies in countries has a positive and negative side. The benefits of international economic integration can be attributed to the openness of the economy to the foreign markets, the development of information and communication technologies, the enrichment and expansion of the assortment, the change in the social and cultural life of whole society. From the point of view of the country in which the enterprises cooperating within the multinationals among domestic, relatively independent enterprises, disparities in income, employment, remuneration, human resources development, performance management, but also in employee culture, legislative or institutional arrangements occurs.

InternationalHuman ResourcesManagement (IHRM) and multinational companies (MNCs) are the subject of several scientific studies. Cooke et al. (2019) evaluated the current state of research on multinational corporations (MNCs) in the International Human Resources Management (IHRM) literature. Drawing on 342 articles from 39 English journals in the business and management field published over the period 2000-2014. They have concluded that the rise in MNCs from emerging markets and the growth of transnational alternative investors will influence the change in the research of IHRM and multinational companies. There is potential for comparative analyses and IHRM surveys in countries with transition economies. The interest in examining the development of the economy and the IHRM in countries with transition economies over the decade led the experts (Syllignakis \& Kouretas, 2011; Boratynski et al., 2018; Mulligi et al., 2018, Škare et al., 2018) to opinions that are the subject of scientific discussions. Comparative analysis in advanced and emerging countries focused on country-specific and firm-specific advantages (1), motivations for investing abroad (2) and different modes of entry into foreign markets (3), were conducted by Amighini et al., (2015). They have come to the conclusion that Emerging Economy Multinational Enterprises (EMNEs) do differ from Advanced Country Multinational Enterprises (AMNEs), although these differences may be contingent and transitory.

The study of the special features of Slovak enterprises in the competition of Central and Eastern European countries according to the TOP 500 ranking is the subject of this article. Our aim is to examine the impact of globalization 
on human resources management processes and the competitiveness of Slovak enterprises in the international space, which is bordered by the Central and Eastern European region $(\mathrm{CEE})^{1}$.

\section{Literature Review}

The natural consequence of globalization, pioneered in the 1960 s by the USA, is the involvement of multinational companies in individual countries. The Conference of the United Nations Organization on Trade and Development treats multinational (transnational) corporations as legal entities or entities without legal personality consisting of parent companies and their foreign affiliates. The parent company is defined as an enterprise that controls assets of other entities in countries other than the mother country, usually by owning a capital stake. A foreign affiliate is a legal entity or entity without legal personality in which an investor as a resident of another economy holds a share that allows a long-term interest in the management of that company (UNCTAD, 2018). According to the OECD, multinational companies are one of the most important players in the international economy (Andrenelli, 2018). They influence global competitiveness, trends in international trade, economy of countries with potential benefits and risks (Kordos \& Vojtovic, 2016; Mura et al., 2017).

Multinational companies have headquarters of subsidiaries in countries with a different standard of living and culture, different economic, social, political and legislative systems. The need to communicate with multiple stakeholders and manage them around the world means that managers of multinational companies are confronted with a diversity of values, perspectives and expectations. Effective response to this diversity requires extensive knowledge of regions, customers, subsidiaries, willingness to combine different views into mutual dialogue and decisionmaking, and the ability to balance multiple and often competent interests of stakeholders (Schwartz \& Carroll, 2003). Each multinational company must effectively manage a global workforce, develop and achieve a sustainable competitive advantage (Collings, 2014; Tarique et al., 2016). The management of a global workforce includes cultural, geographic, mobile, and generational challenges beyond those of domestic enterprise (Schuler et al., 2002). According to Dessler (2013), managing human resources internationally creates challenges, first comes from the sometimes vast distance involved, but the bigger issue is coping with the cultural, political, legal, and economic differences among countries.

The heterogeneity of employees requires the adoption of common rules that respect equal opportunities and diversity management. Diversity is also reflected in the structure of employees of multinational companies and in human resources management. In a multinational company, besides local nationals, there are employed expatriates and employees of third countries, i.e. from countries outside the European Union. Compared to expatriates, they are less expensive, communicate fluently in a foreign language, are better prepared for work in different cultural and legislative environment. They mostly work in international project teams within the company and, unlike expatriates, take up employment even under less favourable working conditions (Caligiuri \& Tarique, 2012).

The field of IHRM is about understanding, researching and reviewing all human resource activities in their internal and external contexts, as they are the global environment to enhance the experience of multiple stakeholders. The purpose of International Human Resources Management (IHRM) is to enable the enterprise, specifically the multinational corporation, to be successful globally (Meardi et al., 2009). IHRM brings together people of different cultures and creates the prerequisites for integrating diversity into the values and visions of a company. According to Rotunda (2018), any meaningful progress in achieving diversity and inclusion should be visible and reflected in three main areas of the multinational corporation. These areas include Talent, Clients, and Communities. Talent pillar is global with a focus on leadership positions, the client pillar is a commitment of the company in expanding markets and satisfying differentiated customer needs, and

\footnotetext{
The term CEE includes the Eastern bloc countries west of the post-World War II border with the former Soviet Union (Bulgaria, the Czech Republic, Hungary, Poland, Romania, Slovakia), the independent states in former Yugoslavia (Croatia, Serbia, Slovenia) and the three Baltic states - Estonia, Latvia, Lithuania.
} 
the third pillar focuses on social and economic development with a commitment to be leaders in this development through collaborative efforts in research, strategic partnerships, donations and sponsorships.

We understand IHRM as a set of human resources processes and the latest knowledge enabling businesses to spread and manage their activities abroad. A key advantage of IHRM in a multinational corporation is the ability to transfer and exploit knowledge more effectively and efficiently within their intracorporate network than through external market mechanisms (Simonin \& Özsomer, 2009). All human resource processes are developing in IHRM, however, multinational corporations need to manage the additional challenge of successfully navigating various institutional, social, cultural, political, and economic environments (Thomas \& Lazarova, 2014). IHRM must consider more and different contextual influences (a), operate under a higher level of risk (b), engage in a broader set of activities (c), fulfill many strategic roles (d), and balance the forces towards differentiation versus internal consistency of human resource operations (e). Unlike the human resources management typical for local enterprises, IHRM also includes processes related to administrative service and care for expatriates and their family members, international taxation, international and local labour law and values (traditions), translation services, training for work in the international environment and so on (Dvořáková et al., 2012).

To summarize (Dickmann et al., 2016; Tarique et al., 2016), IHRM focuses on typical HRM activities such as workforce planning, recruitment, selection, training, development, performance appraisal, and compensation in MNCs. It also includes specific processes linked to international (mostly centralized) human resources planning, searching for and getting suitable employees/managers for work at headquarters and top positions of subsidiaries, training and developing intercultural competencies, managing talents, evaluating the performance of organizational components of the company, rewarding senior managers and expatriates, stabilizing competent and high-performing employees. Managers of multinationals must be sensitive to the state administration, the local labour market, public opinion and regulations. Due to the diversity of the company, they should act in accordance with the expectations and legitimate requirements of different stakeholder groups in each country (Stahl et al., 2018).

The human resources management and personnel work methods applied in the parent company are gradually adapting to the conditions of foreign affiliates, as it is not possible to have consistent practices and parent company standards in all countries (Harzing \& Pinnington, 2015). In the global context, the challenges are even more complex, as adaptation pressures are often related to incomplete and inaccurate understanding of local operational contexts and common ways. An example of a misunderstanding of cultural differences is IKEA, which in 2012 removed the pictures of women from the catalogue for Saudi Arabia (Miska \& Plesková, 2016).

Approaches of multinationals to foreign markets are also reflected in the IHRM (Welch \& Björkman, 2015). They influence the degree of convergence (strategic standardization) or divergence (strategic localization) in the attitudes and policies of the multinationals. It is clear that countries are different and MNCs have to consider this and differentiate their HRM practices. The HRM literature generally refers to convergence or divergence and notes that MNCs do not standardize practices even when they have the opportunity to do so (Brewster \& Mayrhofer, 2016).

To what extent can a multinational corporation, according to Perlmutter's initial model (1969), maintain the policy and practices in the IHRM used in the parent company and apply ethnocentric, polycentric or geocentric approach to foreign subsidiaries (Dalton \& Druker, 2012)? Parallel to this, it is important to examine the rate of transfer of best practices in IHRM processes between organizational components of a multinational company (Pudelko \& Harzing, 2007).

In a multinational company that prefers an ethnocentric approach to management, convergence prevails, connected with the creation and application of unified rules and practices in human resources management. The opposite of convergence is divergence. Its essence is in applying procedures and ways of managing human resources that match the local conditions and national culture of the subsidiary (Edwards \& Rees, 2016). In practice, full convergence or divergence is almost 
absent. The ideal solution is the transnational approach of multinational companies to foreign markets based on a mix of procedures and processes of all organizational components (Katz \& Darbishire, 2000). Huczynski and Buchanan (2010) add that convergence and divergence, despite some common features, cannot be confused with centralization and decentralization in human resources management. Centralization means that competence and responsibility are in the hands of top managers of a multinational company, on the other hand, decentralization spreads the power and responsibility for decision-making in the IHRM to managers at the lower levels of the company's organizational hierarchy. MNCs located in CEE countries with transit economies are subject to EU law, the IHRM processes and processes used in parent corporations, and the rules applied in the subsidiaries' headquarters. What management approaches influence the convergence vs. divergence in companies based in Slovakia, ranked in the TOP 500 ranking CEE, is the focus of our research.

\section{Methodology}

After the collapse of the so-called Eastern Bloc of Europe between 1989 and 1990, countries transforming their economies, became part of the Central and Eastern European region (CEE). The CEE countries include the former socialist states, which extend west of Russia, Belarus, Ukraine, Moldova; south of Finland and the Baltic Sea; north of Greece; and east of Austria, Italy and Germany. The countries of the CEE region are members of the European Union and NATO. The subject of this article are the CEE countries and not the group of countries according to OECD ${ }^{2}$.

The main criteria for the evaluation of the largest CEE companies are turnover, net profit and employment for the year under review and changes in relation to the previous year. Rating is done by countries. The largest companies in CEE (Bulgaria, Croatia, the Czech Republic,
Estonia, Hungary, Latvia, Lithuania, Poland, Romania, Serbia, Slovakia and Slovenia) reach turnover $\geq$ EUR 300 million, were identified, excluding financial service providers such as banks, insurance companies, leasing firms and brokers. Turnover and profit were converted into EUR based on the exchange rate at the end of 2017. The data were taken from Coface Infolcon database and supplemented with external information as required (icon.coface. com). In 2017, the average GDP growth rate soaring to its highest level in the last eight years of $4.5 \%$, after $3.1 \%$ in 2016 and $3.7 \%$ in 2015. Coface ${ }^{3}$ forecasts indicate that this will remain at a solid $4.1 \%$ next year (www.coface. com). The CEE TOP 500 outlines the economic situation at the 500 largest companies in CEE, measured by turnover. Overall turnover at the 500 top companies increased steeply by $11.8 \%$ to EUR 652 billion. Aggregated net profits amounted to EUR 31,496 million (+16.2\%) and employment at the 500 largest companies to 2.4 million people $(+4.7 \%)$.

Among the five key CEE sectors of the largest companies are minerals, chemicals, petroleum, plastics and pharmaceutics (151), automotive and transport (138), non-specialized trade (98), utilities and public services (90) and electronics, information and telecommunication (72). Slovakia is ranked fifth in the TOP 500 ranking CEE behind Poland, Hungary, the Czech Republic and Romania (Tab. 1). According to the number of employees in the TOP 500 companies by country compared with the national labour force, Slovakia is in the 4th place $(4.4 \%)$ behind Lithuania (10.5\%), Poland $(7.4 \%)$ and Hungary $(5.3 \%)$. According to the GDP per capita in thousands of EUR, the ranking of countries is as follows: Slovenia (21), the Czech Republic (18.7), Estonia (17.5), Slovakia (15.6), Lithuania (14.8), Latvia (13.9), Poland (12), Hungary (11.8), Croatia (11.1), Romania (9.6), Bulgaria (7.1), Serbia (5). The negative impact on Slovakia is the unemployment rate $(8.1 \%)$ and the falling GDP growth per capita.

\footnotetext{
2 The Organisation for Economic Co-operation and Development also uses the term "Central and Eastern European Countries (CEECs)" for a group of countries comprising Albania, Bulgaria, Croatia, the Czech Republic, Hungary, Poland, Romania, the Slovak Republic, Slovenia, and the three Baltic States: Estonia, Latvia and Lithuania (https:// stats.oecd.org/glossary/detail.asp?ID=303).

3 Coface group (Vienna, Austria) has contributed since its establishment (1946) to the performance and growth of enterprises. Coface Central Europe is the leading provider of business information in Central and Eastern Europe. The basis for the evaluation is the financial data of Info Icon. Overview of the results of CEE countries with transition economies has been provided since 2008.
} 


\section{Finance}

\section{Tab. 1: Coface CEE TOP 500 in 2017 - country overview}

\begin{tabular}{|c|c|c|c|c|c|c|c|c|c|c|c|c|}
\hline $\begin{array}{l}\text { 訔 } \\
\text { 品 }\end{array}$ & $\begin{array}{l}\text { DE } \\
\text { 咅 }\end{array}$ & 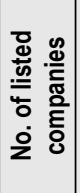 & 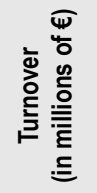 & 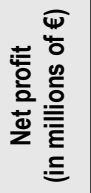 & 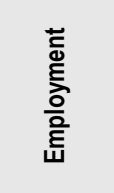 & 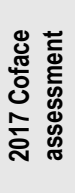 & 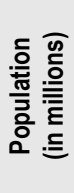 & 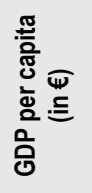 & 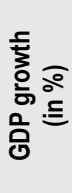 & 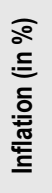 & 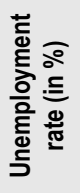 & 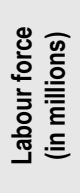 \\
\hline 1 & Poland & 175 & 262,357 & 10,887 & $1,242,681$ & A3 & 38.4 & 12,000 & 4.6 & 2.0 & 4.9 & 16.9 \\
\hline 2 & Hungary & 71 & 95,698 & 5,204 & 244,395 & A3 & 9.8 & 11,800 & 4.0 & 2.4 & 4.2 & 4.6 \\
\hline 3 & Czech Rep. & 67 & 97,249 & 5,265 & 238,520 & A2 & 10.6 & 18,700 & 4.3 & 2.4 & 2.9 & 5.3 \\
\hline 4 & Romania & 56 & 58,618 & 3,050 & 201,284 & A4 & 19.5 & 9,600 & 6.9 & 1.3 & 4.9 & 8.8 \\
\hline 5 & Slovakia & 43 & 49,510 & 3,198 & 119,642 & A3 & 5.4 & 15,600 & 3.4 & 1.3 & 8.1 & 2.7 \\
\hline 6 & Lithuania & 19 & 21,270 & 958 & 146,544 & A3 & 2.8 & 14,800 & 3.8 & 3.7 & 7.1 & 1.4 \\
\hline 7 & Bulgaria & 17 & 18,552 & 724 & 23,274 & A4 & 7.1 & 7,100 & 3.6 & 1.2 & 6.2 & 3.3 \\
\hline 8 & Slovenia & 15 & 17,829 & 232 & 30,853 & A3 & 2.1 & 21,000 & 5.0 & 1.4 & 6.6 & 1.0 \\
\hline 9 & Croatia & 14 & 10,772 & 682 & 43,248 & B & 4.2 & 11,100 & 2.9 & 1.1 & 11.1 & 1.8 \\
\hline 10 & Serbia & 10 & 9,604 & 622 & 71,152 & B & 7.0 & 5,000 & 1.9 & 3.1 & 14.7 & 3.2 \\
\hline 11 & Estonia & 7 & 4,951 & 239 & 30,635 & $\mathrm{~A} 2$ & 1.3 & 17,500 & 4.9 & 3.7 & 5.8 & 0.7 \\
\hline 12 & Latvia & 6 & 5,260 & 436 & 18,033 & A3 & 2.0 & 13,900 & 4.5 & 2.9 & 8.7 & 1.0 \\
\hline
\end{tabular}

Source: Coface, 2018

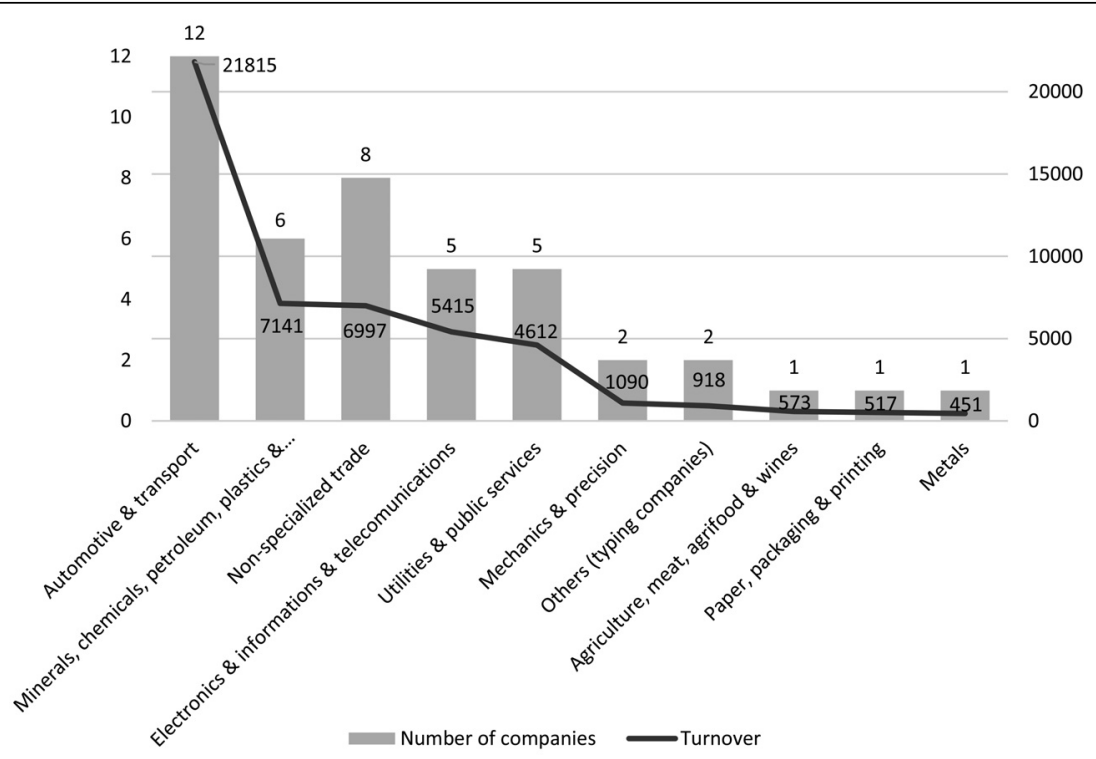

Source: Own processing by Coface, 2018 
Slovakia is a country represented by 43 largest companies with an aggregate revenue of EUR 49.51 billion in 2017. Among the top ten largest companies based in Slovakia are: Volkswagen Slovakia $\left(7^{\text {th }}\right.$ place in Coface TOP 500), Kia Motors Slovakia (13), Slovnaft (27), PCA Slovakia (41), Samsung Electronics Slovakia (44), Slovenské elektrárne (61), Slovenský plynárenský priemysel (114), Tesco Stores SK (118), Mobis Slovakia (123) and Okte (138). The automotive industry is strongly represented by the largest companies (12) with turnover of 21.815 billion in the country. Representation of Slovak sectors by number of companies and turnover in mil. EUR is shown in Fig. 1.

We addressed all 43 companies ranked in the Coface TOP 500 and asked them to participate in our survey about HRM processes and companies' approaches to foreign markets. A total of $36 \mathrm{HR}$ managers (83.2\%) agreed and formed our research sample. The survey was conducted by sociological inquiry and interviews using structured questionnaires. When examining, we combined qualitative and quantitative methods. We consider the qualitative methods as a well established philosophy of social research (Silverman, 1985) and appropriate to our research objectives. We verified the possible existence of interrelation of the selected approach to human resource management and implementation of convergence vs. divergence by appropriate statistical tests.

The structure of Slovak enterprises in the Coface TOP 500 ranking is represented by $35(81.4 \%)$ enterprises, which are a part of multinational companies. The rest of them is exclusively in Slovak ownership. There is a $100 \%$ share of multinational companies in the electronics, information and telecommunication sector; in the automotive \& transport sector only 1 of 12 successful Slovak national enterprises (state railway company) and 11 subsidiaries belonging to multinational companies. The prevalence of multinational companies is also in the minerals \& pharma sector $(83.3 \%)$, nonspecialized trade (87.5\%), mechanics $(100 \%)$, paper $(100 \%)$, agriculture $(100 \%)$. Slovak joint-stock companies are represented in the utilities and public services sector, while the majority shareholder of Slovenské elektrárne is a foreign investor and the majority $(51 \%)$ owned by the state and $49 \%$ are foreign capital. In the "Others" sector, there is 1 Slovak company (TIPOS) and one subsidiary company.
The research sample (36 enterprises) consists of 7 multinational retail chains (Tesco Stores, Kaufland, Lidl, Tesco International Clothing, Billa, Ikea, Metro), 4 enterprises of electrotechnical, information and telecommunication (Samsung, Slovak Telecom, Orange, Eset), Automotive and Transport sector (Wolkswagen, Kia Motors, PCA, ŽSSK, Faurecia Automotive, Adient, Continental Matador Truck, SAS automotive, Continental Matador Rubber, Mobis), 5 Mineral and Pharma Companies (Slovnaft, SPP, Unipetrol Slovakia, Phoenix, OMV), 5 companies from utilities and public services (Slovenské elektrárne, Západoslovenská energetika, Stredoslovenská energetika, Západoslovenská distribučná, Stredoslovenská distribučná), 1 company from paper industry (Mondi SCP), 2 companies from mechanics (Schaeffler Skalica, Schaeffler Kysuce) and 2 betting companies (Tipos, Niké). The structure of the sample is presented by 7 enterprises with majority Slovak capital and $29(80.1 \%)$ enterprises with superiority of foreign capital. There is also ESET (internet security company) among the companies with predominant Slovak capital, which has its subsidiaries in more than 200 countries worldwide.

By our survey, we verified 2 assumptions:

1. the level of convergence or divergence is

a consequence of the company's approach to foreign markets,

2. the performance of HRM processes in MNCs and local enterprises is different in more than a half of the processes.

We verified the assumptions on the sample of the 36 largest Slovak companies among CEE region. When examining the performance of HRM processes, we compared the results of the findings with the survey results we made in 2017 (Vetráková et al., 2017). By sociological inquiry, we received the views of human resources experts from 381 private sector $(88 \%)$ and the public sector (12\%) companies. There was a predominance of small enterprises $(54.6 \%)$ in private sector, and the enterprises with a number of employees from 50 to 249 in public sector, which corresponds to the structure of private and public sector enterprises in Slovakia.

We tried to verify the possible interrelation of the chosen approach to human resources management and implementation of convergence or divergence. We asked the respondents which of the approaches to IHRM 
is applied in their company. The following question was about the practices (convergence, divergence or combination) they use in IHRM. Since both variables are categorical, the chisquare test of independence was used. This type of statistical testing is applied when both variables are both categorical. The null hypothesis $\left(\mathrm{H}_{0}\right)$ in chi-square tests is that there is no relationship between the independent and dependent variables. The alternative hypothesis $\left(\mathrm{H}_{1}\right)$, on the other hand, predicts that there is a relationship (Härdle \& Simar, 2012). We verified the hypotheses at the significance level $\alpha=0.05$. The obtained $p$-value must be less than this value in order for the alternative hypothesis to be accepted by rejecting the null hypothesis.

However, we encountered one problem when applying the chi-square test. Up to $77.8 \%$ cells have expected count less than 5 , which violated one of the assumptions of the test and puts our results under question. That's why we have run another test to dispel any doubts. This time we used Fisher's exact test. It is used to determine if there are non-random associations between two categorical variables. It is a statistical measure of association based not on calculation of probabilities from a distribution (as in chi-square or $t$-tests), but from a factorial formula. Unlike most statistical tests, Fisher's exact test does not use a mathematical function that estimates the probability of a value of a test statistic; instead, it calculates the probability of getting the observed data, and all data sets with more extreme deviations. The null hypothesis $\left(\mathrm{H}_{0}\right)$ is that the relative proportions of one variable are independent of the second variable; in other words, the proportions at one variable are the same for different values of the second variable. The alternative hypothesis $\left(\mathrm{H}_{1}\right)$ is that the observed variables are dependent (VanPool \& Leonard, 2011). We verified the hypotheses at the significance level $\alpha=0.05$. The obtained $p$-value must be less than this value in order for the alternative hypothesis to be accepted by rejecting the null hypothesis.

To determine the strength of the dependence, we used the Cramer's $\mathrm{V}$ test. It is a way of calculating correlation in tables which have more than $2 \times 2$ rows and columns. It is used as post-test to determine strengths of association after other test has determined significance. Tests such as chi-square or Fisher's exact test say if there is a significant relationship between variables, but they do not say just how significant and important this is. Cramer's $\mathrm{V}$ is a post-test to give this additional information. The null hypothesis $\left(\mathrm{H}_{0}\right)$ is that there is no difference between the groups and equality between means. The alternative hypothesis $\left(\mathrm{H}_{1}\right)$ is that there is a difference between the means and groups. Cramer's $V$ varies between 0 and 1 . Close to 0 it shows little association between variables. Close to 1 , it indicates a strong association (Agresti, 1996).

To verify the assumption about the difference in performance of HRM processes in MNCs and local enterprises, we asked the respondents which of the HR processes are performed in their company. We used Mann-Whitney $U$ test to find out if there are statistically significant differences between the performance of HR processes in MNCs and local enterprise. The Mann-Whitney $U$ test can be used to answer the questions concerning the difference between groups. This test has the great advantage of possibly being used for small samples of subjects. In the field of behavioural sciences, the Mann-Whitney $\mathrm{U}$ test is one of the most commonly used nonparametric statistical tests (Kasuya, 2001). Its null hypothesis $\left(\mathrm{H}_{0}\right)$ assumes that the two groups come from the same population. In other words, it assumes that the two independent groups are homogeneous and have the same distribution. The alternative hypothesis $\left(\mathrm{H}_{1}\right)$ against which the null hypothesis is tested assumes that the first group data distribution differs from the second group data distribution. The Mann-Whitney $U$ test is based on the comparison of each observation from the first group with each observation from the second group (Nachar, 2008).

\section{Results and Discussion}

Survey results in analysed enterprises point to differentiated HRM approaches. The reason for the differences is mainly the location of the parent company, the accepted national and corporate culture, the age of the enterprise, the ownership and the core business. Establishing MNCs in Slovakia have begun in the 1990s. Although, the history of many companies that have become part of multinational corporations dates back to the early 20th century. An example is the development of Continental Matador Rubber (MR) and Continental Matador Truck Tires (MTT). Both companies have their 


\section{Fig. 2: Establishment of MNCs in Slovakia}

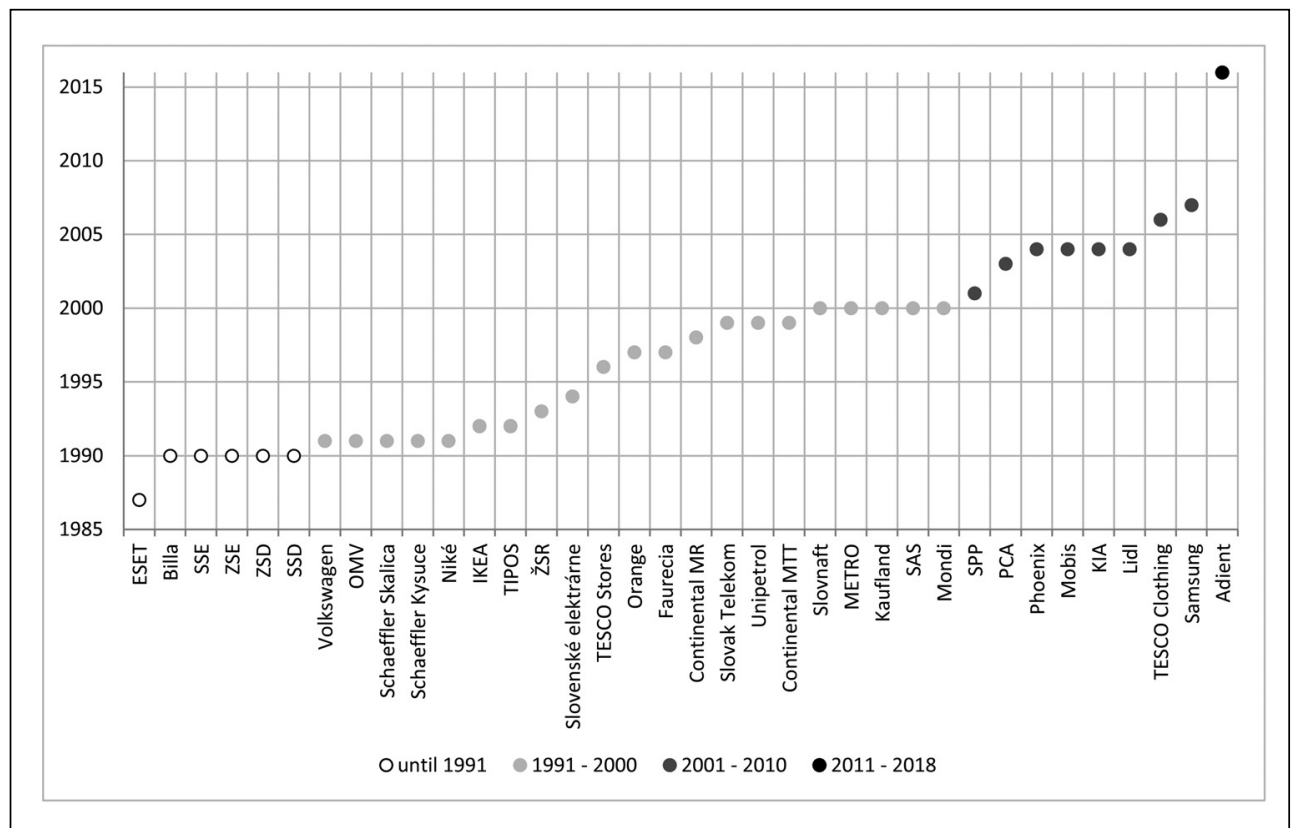

Source: Own processing

foundations in Matador, a company that was founded in 1905. Significant change in company development occurs after 1998, when the contract with the German concern Continental was signed. Under the current brands, they have been operating on the market since 2007. Even older history is noted in Mondi, whose origins date back to 1697 , when manual paper production began in Ružomberok. In 2000 , paper mill in Ružomberok became the strategic partner of MONDI group and in 2008 changed its name to MONDI SCP. There are 7 largest companies older than 30 years ranked in Coface TOP 500 CEE, 20 of them were founded between 21 and 30 years ago (established between 1991 and 2000). There are 8 companies created between the years 2001-2010, and Adient was created in 2016 by the separation from Johnson Controls Automotive Slovakia. An overview of the establishment of MNCs in time is in Fig. 2.

In the early years of joint venture, in the MNCs operating in Slovakia, the ethnocentric approach in management dominated, the increasingly common HRM rules and procedures adapted to the specificities of national culture and legislation. According to the survey, the ethnocentric approach of management to organizational components is applied in 16 companies $(44.4 \%)$. This approach is typical for Slovak companies with state ownership, as well as for companies with parent companies in neighbouring or Asian countries. According to the Volkswagen representative, the impact of German culture has been mainly reflected in the introduction of work practices and behaviour rules, job discipline and performance assessment, planning, errors removal, monitoring of efficiency and quality of work. Ethnocentrism has a logical rationale in HRM processes such as achieving corporate identity by respecting a common vision, mission, and company strategy, in some cases even a common logo and uniform. Regardless of the company's approach to foreign markets, the survey showed that in $77.8 \%$ of the largest surveyed companies, with respect to the capital invested in international business, there 
is a strong centralization in the monitoring of financial situation of the subsidiaries, the benchmarking of selected indicators in the company, the weekly and monthly reports economic indicators, regular reporting on the financial and personal situation of the subsidiary.

The polycentric approach, characterized by a higher empowerment of subsidiaries in the decision-making and support of HRM processes, is applied by 8 companies $(22.2 \%)$, and 12 companies (33.3\%) have adopted the transnational approach. The common feature of the surveyed companies is building the sense of belonging among employees in both the subsidiary and the parent company. The advantage of multinational companies compared to local enterprises is the application of internationally proven functional processes in multiple countries, new ways to solve problems, and the use of best practices in HRM. The survey confirmed the views of experts on the need for a better understanding of the culture of each country in which the multinational company is located with its subsidiaries and the need to respect national, especially legislative and business specifics (83.3\%). Kia's human resource manager considers the implementation of Slovak legislation into corporate governance practices and clarifying attitudes and differences in HRM and the organization of work as the most difficult roles in setting up a business in Slovakia in 2004. According to the human resources manager at Tesco stores, a healthy competition contributes to achieving good economic results as well as customer satisfaction. The company applies a transnational approach to managing subsidiaries while respecting commonly agreed anti-corruption policy rules, rules for sending expatriates from the UK to other countries, strategic decisions on company development, taking into account valid legislation of the country.

For verification of possible interrelation of the chosen approach to human resources management and implementation of convergence or divergence, the chi-square test of independence was used. The test results are shown in Tab. 2.

The calculated $p$-value is less than $\alpha=0.05$, therefore we reject $\mathrm{H}_{0}$ and we claim that there is a statistically significant relationship between the observed variables. However, we encountered one problem when applying the chi-square test. Up to $77.8 \%$ cells have expected count less than 5 , which violated one of the assumptions of the test and puts our results under question. That's why we have taken into consideration the results of Fisher's Exact Test to dispel any doubts. The test results are also shown in Tab. 2. The calculated $p$-value is less than $\alpha=$ 0.05 , so we reject the $\mathrm{H}_{0}$ and claim that there is a statistically significant dependence between

Tab. 2: Results of chi-square tests

\begin{tabular}{|c|c|c|c|c|c|c|}
\hline & \multirow{3}{*}{ Value } & \multirow{3}{*}{ df } & \multirow{3}{*}{$\begin{array}{c}\text { Asymptotic } \\
\text { Significance } \\
\text { (2-sided) }\end{array}$} & \multicolumn{3}{|c|}{ Monte Carlo Sig. (2-sided) } \\
\hline & & & & \multirow{2}{*}{ Significance } & \multicolumn{2}{|c|}{$\begin{array}{l}\text { 95\% Confidence } \\
\text { Interval }\end{array}$} \\
\hline & & & & & $\begin{array}{l}\text { Lower } \\
\text { Bound }\end{array}$ & $\begin{array}{l}\text { Upper } \\
\text { Bound }\end{array}$ \\
\hline Pearson Chi-Square & $55.153^{a}$ & 4 & 0.000 & $0.000^{\mathrm{b}}$ & 0.000 & 0.000 \\
\hline Likelihood Ratio & 56.120 & 4 & 0.000 & $0.000^{\mathrm{b}}$ & 0.000 & 0.000 \\
\hline Fisher's Exact Test & 46.254 & & & $0.000^{\mathrm{b}}$ & 0.000 & 0.000 \\
\hline $\begin{array}{l}\text { Linear-by-Linear } \\
\text { Association }\end{array}$ & $27.661^{c}$ & 1 & 0.000 & $0.000^{\mathrm{b}}$ & 0.000 & 0.000 \\
\hline $\mathrm{N}$ of Valid Cases & 36 & & & & & \\
\hline
\end{tabular}

Source: own processing

Notes: a. 7 cells $(77,8 \%)$ have expected count less than 5 . The minimum expected count is 2,22 .

b. Based on 10000 sampled tables with starting seed 2000000.

c. The standardized statistic is 5,259 . 


\section{Symmetric Measures}

\begin{tabular}{l|l|c|c|c|c}
\hline \multicolumn{2}{l|}{} & Value & $\begin{array}{c}\text { Asymptotic Stan- } \\
\text { dardized Error }\end{array}$ & $\begin{array}{c}\text { Approx. } \\
\text { T }\end{array}$ & $\begin{array}{c}\text { Approx. } \\
\text { Sig. }\end{array}$ \\
\hline \multirow{2}{*}{ Nominal by Nominal } & Phi & 1.238 & & & 0.000 \\
\cline { 2 - 6 } & Cramer's V & 0.875 & & & 0.000 \\
\hline Interval by Interval & Pearson's R & 0.889 & 0.074 & 11.321 & 0.000 \\
\hline Ordinal by Ordinal & Spearman Correlation & 0.888 & 0.076 & 11.286 & 0.000 \\
\hline N of Valid Cases & 36 & & & \\
\hline
\end{tabular}

Source: own processing

Notes: a. Not assuming the null hypothesis.

variables and therefore the implementation of convergence, divergence or their combination depends on the chosen approach to human resources in the company. Since all of the assumptions were met, the Fisher's Exact Test results confirmed chi-square test results. To determine the strength of the dependence, we used the Cramer's $\mathrm{V}$ test. The results are shown in Tab. 3.

The calculated value of Cramer's $V$ is 0.875 , which is a strong dependence, confirming the assumption that the convergence vs. the divergence is the result of the company's approach to HRM in its subsidiaries.

The percentage of performance of HRM processes in the largest Slovak companies and local enterprises is in Tab. 4. Managers of local enterprises are focused mostly on employee selection (90.8\%), while in MNCs strategy and human resources policies are the most important ones. In MNCs, the emphasis is placed on conceptual issues of company development; in local enterprises dominate operations and solving of everyday work problems. The same number $(69.5 \%)$ of MNCs and local enterprises responded to the lack of qualified job seekers and employees capable and willing to perform their work. According to $77.2 \%$ of local enterprises managers, HRM problems include inadequate work discipline and communication, falling reliability and responsibility, dissatisfaction with payroll, declining performance and employee fluctuations, and increasing staffing demands. Managers are aware that the level of HRM processes is the determinant that distinguishes the best and most successful enterprises from the others. Nevertheless, they focus on the material, technical and financial security of the company's activities and spend less time on human resources. Employees are looking for enterprises that have a good reputation and are financially stable not only at home but also abroad. This is one of the reasons for the growing shortage of qualified candidates in the Slovak labour market.

In both MNCs and local enterprises, the same philosophy is adopted in the recruitment and adaptation processes. Most managers are of the opinion that, in the process of adapting systematically and focusing on the content of work, recruited employees are able to better integrate into the social, working and cultural environment of an enterprise. The employment relationship will end with employees who cannot adapt. Employee education and development is an important process of HRM in both surveys. In MNCs, unlike local enterprises, there is greater career development and employment opportunities in organizational parts of the company. Based on the assessment of the HRM processes in the MNC, the most important are human resource strategy and policy $(91.7 \%)$, training and development $(86.1 \%)$, hiring and adaptation $(80.6 \%)$, human resource planning $(77.8 \%)$, assessment and management of work performance (75\%). In local enterprises, the most attention is paid to the selection of employees $(90.8 \%)$, hiring and adaptation (86.6\%), training and development $(82.6 \%)$, employee safety and conditions $(79.5 \%)$, evaluation and management of work performance $(79.2 \%)$.

To verify the assumption about the difference 
Tab. 4:

The performance of HRM processes (\%)

\begin{tabular}{l|c|c}
\multicolumn{1}{c|}{ Processes } & MNCs & Local Enterprises \\
\hline Human resources selection & 55.56 & 90.81 \\
\hline Hiring and adaptation of employees & 80.56 & 86.61 \\
\hline Job evaluation & 58.33 & 36.22 \\
\hline Talent management & 83.33 & 17.85 \\
\hline Training and development & 86.11 & 82.68 \\
\hline Employees safety and conditions & 52.78 & 79.53 \\
\hline Human resources planning & 77.78 & 71.92 \\
\hline Layoffs & 30.56 & 51.97 \\
\hline Job analysis & 58.33 & 55.64 \\
\hline Human resource strategy, policy & 91.67 & 49.61 \\
\hline Performance evaluation & 75.00 & 79.27 \\
\hline Personnel controlling and auditing & 52.78 & 41.73 \\
\hline
\end{tabular}

Source: own processing

\section{Tab. 5: Results of Mann-Whitney U test}

\begin{tabular}{l|c|c|c|c}
\multicolumn{2}{c}{ Test Statistics } \\
& Mann-Whitney U & Wilcoxon W & Z & $\begin{array}{c}\text { Asymp. Sig. } \\
\text { (2-tailed) }\end{array}$ \\
\hline HR selection & 5940.000 & 78711.000 & -2.340 & 0.019 \\
\hline Hiring and adaptation of employees & 6288.000 & 79059.000 & -1.221 & 0.222 \\
\hline Job evaluation & 4830.000 & 5496.000 & -3.488 & 0.000 \\
\hline Talent management & 5284.500 & 5950.500 & -3.089 & 0.002 \\
\hline Training and development & 6414.000 & 79185.000 & -0.987 & 0.324 \\
\hline Employees safety and conditions & 5857.500 & 6523.500 & -1.992 & 0.046 \\
\hline HR planning & 5848.500 & 78619.500 & -1.892 & 0.059 \\
\hline Layoffs & 5407.500 & 78178.500 & -2.423 & 0.015 \\
\hline Job analysis & 5268.000 & 78039.000 & -2.680 & 0.007 \\
\hline HR strategy and policy & 5554.500 & 6220.500 & -2.183 & 0.029 \\
\hline Performance evaluation & 6543.000 & 79314.000 & -0.648 & 0.517 \\
\hline Personnel controlling and auditing & 5475.000 & 78246.000 & -2.335 & 0.020 \\
\hline
\end{tabular}

Source: own processing

Notes: a. Grouping Variable: Category. 
in performance of HRM processes in MNCs and local enterprises, we used Mann-Whitney $U$ test. The results of our testing are in Tab. 5 .

The calculated $p$-values are lower than $\alpha=$ 0.05 in 8 out of $12 \mathrm{HR}$ processes (HR selection, job evaluation, talent management, employees safety and conditions, layoffs, job analysis, HR strategy and policy formation and personnel controlling and auditing). We claim that there is no dependence between the performance of mentioned HRM processes in MNCs and local enterprises. We have thus confirmed the assumption that the performance of HRM processes in MNCs and local enterprises is different in more than a half of the processes.

\section{Conclusion}

The CEE TOP 500 outlines the economic situation of the 500 largest companies in CEE, measured by turnover. Slovakia ranked fifth in the TOP 500 ranking CEE behind Poland, Hungary, the Czech Republic and Romania. Slovakia is a country represented by 43 largest companies with an aggregate revenue of EUR 49.51 billion in 2017. In comparison with the previous year, the turnover of companies located in Slovakia grew by $3.9 \%$, while the growth rate of the TOP 500 companies was higher (11.8\%). The reason for the slower growth is the decline in turnover mainly in the automotive industry and the retail chains. Companies belonging to the electrotechnical and telecommunications sector and minerals achieved growth of turnover. Of the 43 companies, up to $35(81.4 \%)$ are part of the MNCs. This makes it clear that MNCs have a leading position in Slovakia's competitiveness in CEE. We tested 2 assumptions on a sample of 36 companies belonging to CEE TOP 500 . We were interested in finding out if the convergence vs. the divergence is a consequence of the company's approach to HRM, and whether the performance of HRM processes in MNCs and local enterprises is different.

Multinational companies and their activities in Slovakia significantly influence business and international trade. The proof of this statement is also an overview of the most successful companies TOP 200 Slovakia, which is dominated by multinational companies. Our research confirmed the original assumption that the degree of convergence and divergence depends on access to foreign markets.

According to the survey, the ethnocentric approach of management to organizational components is applied in $44.4 \%$ of companies. This approach is typical for Slovak companies with state representation, as well as for companies with parent companies in neighbouring or Asian countries. A polycentric approach, characterized by a higher empowerment of subsidiaries in the decisionmaking and support of HRM processes, is applied in $22.2 \%$ of companies, and the $33.3 \%$ of companies adopted the transnational approach. The competitive advantage of convergence is the standardization of procedures, adaptation to common HRM processes and practices, which characterizes the behaviour of most Slovaks. The common feature of the companies under examination is to promote corporate identity and employee involvement to the subsidiary and parent company. Using the chi-square test and the Fisher's exact test, we found that there is a statistically significant difference between enterprises in which different approaches are applied in relation to the application of convergence or divergence. We used the Cramer's $\mathrm{V}$ test to determine the strength of the dependence. The result of the verification is the strong dependence of the variables examined, which confirms the assumption that the convergence or divergence in HRM is the result of the company's approach to running its subsidiary.

Ranking of the performance of HRM processes in MNCs and local enterprises stems from a differentiated policy based on strategic and/or operational management. In MNCs, the emphasis is placed on conceptual issues of company development while in local enterprises dominate operatives and solving of everyday work problems. Managers of local enterprises pay the most attention to employee selection (90.8\%), while in MNCs strategy and human resources policy. The advantage of MNCs is the possibility of work placements abroad, career development, wider learning opportunities and self-realization. Those are the benefits that don't exist in local enterprises. An example in MNCs is the succession management, the search for and support for high-performance, talented, committed and loyal individuals (talent pool). Managers of the surveyed companies are aware that the level of HRM processes is the determinant that distinguishes the best and most successful enterprises from the others. Nonetheless, they focus on the material, technical and financial 
security of the local enterprises and spend less time on human resources. To verify the assumption of the difference in performance of HRM processes in MNCs and local enterprises, we used Mann-Whitney $U$ test to find out if the performance of HRM processes in MNCs and local enterprises is different in more than a half of the processes. The results have shown that there are statistically significant differences in performance of HR selection, job evaluation, talent management, employees' safety and conditions, layoffs, job analysis, HR strategy and policy formation and personnel controlling and auditing, that is eight out of twelve HR processes. Our assumption have thus been confirmed.

The composition of the TOP 500 CEE companies is rather heterogeneous. This is understandable because business is affected by many factors such as industry, location, access to resources, access to markets, and much more. On the example of Slovak companies, however, we see that those ones that cross the boundaries of the parent country and try to get together in order to expand their entrepreneurial activity come to the fore. However, this also brings about a change of reasoning and a focus on activities such as strategic management and planning or future development. In order to maintain competitiveness, other Slovak enterprises will have to accept these trends and move closer to the philosophy of MNCs when opening up new challenges and new opportunities.

The survey that we conducted in selected MNCs has some limitations. In sociological inquiry, we included HR managers/officers of companies based in Slovakia and did not examine the opinions of managers of parent MNCs. We have found that MNCs face the dilemma of finding and implementing the best IHRM method taking into account the requirements and opinions of home-country and host-country managers. Creating synergies in HRM process management implies applying a geocentric approach to governance based on the same degree of convergence and divergence. Further research will therefore focus on the transfer of HR policies and practices in MNCs supporting the transnational perspective. The effectiveness of this approach is in linking and combining standardized procedures with different ones to accept the parent company's strategy while meeting internal customer requirements.
Another limitation is the size and quality of research sample. One of the problem is, that there is a big difference in the size of compared groups of companies. This is partly because we have compared the results of two different studies. While one focused on national enterprises, the other one was focused on multinational companies, especially those ranked in the top Coface TOP 500 CEE rankings. This fact also caused the unrepresentativeness of the research sample.

\section{References}

Agresti, A. (1996). Introduction to categorical data analysis. New York, NY: John Wiley and Sons.

Amighini, A. A., Cozza, C., Guiliani, E., \& Scalera, V. G. (2015). Multinational enterprises from emerging economies: what theories suggest, what evidence shows. A literature review. Economia e Politica Industriate, 42(3), 343-370. http://doi.org/10.1007/s40812-015-0011-8.

Andrenelli, A. et al. (2018). Multinational production and trade in services. OECD Trade Policy Papers, 212, Paris: OECD Publishing. http://dx.doi.org/10.1787/16ec6b55-en.

Boratynski, J., Borowski, J., Czerniak, A., \& Rosati, D. (2018). Sectoral Decomposition of the Balassa-Samuelson Effect in CEE Countries: A CGE Analysis. Journal Eastern European Economic, 56(6), 471-503. https://doi.org/10.1080/00128775.2018.1552521.

Brewster, W., \& Mayrhofer, A. (2016). Smale Crossing the streams: HRM in multinational enterprises and comparative HRM. Human Resource Management Review, 26(4), 285-297. http://dx.doi.org/10.1016/j. hrmr.2016.04.002.

Caligiuri, P., \& Tarique, I. (2012). Dynamic cross-cultural competencies and global leadership effectiveness. Journal of World Business, 47(4), 612-622.

Coface CEE TOP 500 COMPANIES - 2018 EDITION. (2018). Retrieved from https://www. coface.com/News-Publications/Publications/ Coface-CEE-TOP-500-Companies-2018Edition.

Coface Infolcon database. (2018). Retrieved November 11, 2018, from https://www. cofacecentraleurope.com/Our-offer/OnlineTools/InfolCON.

Collings, D. G. (2014). Integrating global mobility and global talent management: Exploring the challenges strategic opportunities. 
Journal of World Business, 49(2), 253-261. http://doi.org/10.1016/j.jwb.2013.11.009.

Cooke, F. L., Wood, G., Wang, M., \& Veen A. (2019). How far has international HRM travelled? A systematic review of literature on multinational corporations (2000-2014). Human Resource Management Review, 29(1), 59-75. https://doi.org/10.1016/j.hrmr.2018.05.001.

Dalton, K., \& Druker, J. (2012). Transferring HR concepts and practices within multi-national corporations in Romania: The management experience. European Management Journal, 30(6), 588-602. http://doi.org/10.1016/j.emj.2011.12.003.

Dessler, G. (2013). Human Resource Management. Boston, MA: Pearson.

Dickmann, M., Brewster, Ch., \& Sparrow, P. (2016). International Human Resource Management. New York/London: Routledge.

Dvořáková, Z. et al. (2012). Řizení lidských zdrojů. Praha: C. H. Beck.

Edwards, T., \& Rees, C. (2016). International human resource management: National systems and multinational companies. Harlow: Pearson.

Härdle, W. K., \& Simar, L. (2012). Applied Multivariate Statistical Analysis. Berlin: Springer.

Harzing, A. W., \& Pinnington, A. H. (2015). International Human Resource Management. Los Angeles, CA: Sage.

Huczynski, D. A., \& Buchanan, A. A. (2010). Organizational Behaviour. Harlow: Pearson Education.

Kasuya, E. (2001). Mann-Whitney U test when variances are unequal. Animal Behavior, 61, 1247-1249, https://doi.org/10.1006/anbe.

Katz, H. C., \& Darbishire, O. (2000). Converging divergences: Worldwide changes in employment systems. Ithaca, NY: Cornell University Press.

Kordos, M., \& Vojtovic, S. (2016). Transnational Corporations in the Global World Economic Environment. Procedia - Social and Behavioral Sciences, 230, 150-158. https://doi. org/10.1016/j.sbspro.2016.09.019.

Kosír, I. (2016). Pozitíva a negatíva etablovania nadnárodných spoločností na Slovensku, 10-45. In Formovanie organizačnej kultúry $v$ podnikoch pôsobiacich v interkultúrnom prostredí. Edited by Vetráková, M. (2016). Banská Bystrica: Belianum.

Meardi, G., Marginson, P., Fichter, M., Frybes, M., Stanojević, M., \& Toth, A. (2009). Varieties of multinationals: Adapting employment practices in Central Eastern Europe. Industrial Relations,
48(3), 489-511. https://doi.org/10.1111/j.1468232X.2009.00570.x.

Miska, C., \& Pleskova, M. (2016). IKEA's ethical controversies in Saudi Arabia. In Barmeyer, C. \& Franklin, P. (Eds), Intercultural management: A case-based approach to achieving complementary and synergy, 120-133. New York, NY: Palgrave Macmillan.

Mulligi, A., Adnett, N., Hisarcikilar, M., \& Rizvanolli, A. (2018). Human Capital and International Competitiveness in Europe, with Special Reference to Transition Economies. Journal Eastern European Economic, 56(6), 541-563. htps://doi.org/10.1080/00128775.201 8.1502612 .

Mura, L., Kljucnikov, A., Tvaronaviciene, M., \& Androniceanu, A. (2017). Development Trends in Human Resource Management in Small and Medium Enterprises in the Visegrad Group. Acta Polytechnica Hungarica, 14(2), 105-122.

Perlmutter, H. V. (1969). The tortuous evolution of the multinational corporation. Columbia Journal of World Business, 4, 9-18.

Nachar, N. (2008). The Mann-Whitney U: A Test for Assessing Whether Two Independent Samples Come from the Same Distribution. Tutorials in Quantitative Methods for Psychology, 4(1), 13-20. http://doi. org/10.20982/tqmp.04.1.p013.

Pudelko, M., \& Harzing, A. W. (2007). Country-of-origin, localization, or dominance effect? An empirical investigation of HRM practices in foreign subsidiaries. Human Resource Management, 46(4), 535-559. https:// doi.org/10.1002/hrm.20181.

Rotunda, M. (2018). Building of Inclusion at the Royal Bank of Canada: Strategies for Aboriginal Peoples and Newcomers to Canada, 294-317. In Christiansen, C., Biron, M., Farandale, E., \& Kuvas, B. (editors) (2018). The Global Human Resource Management Casebook. New York, NY: Routledge.

Schuler, R. S., Budhwar, P. S., \& Florkowski, G. W. (2002). International human resource management: Review and critique. International Journal of Management Reviews, 4(1), 41-70. https://doi.org/10.1111/1468-2370.00076.

Schwartz, M., \& Carroll, A. (2003). Corporate Social Responsibility: A Three-Domain Approach. Business Ethics Quarterly, 13, 503530. http://dx.doi.org/10.5840/beq200313435.

Silverman, D. (2005). Ako robit' kvalitatívny výskum. Bratislava: Ikar. 
Simonin, B. L., \& Özsomer, A. (2009). Knowledge processes and learning outcomes in MNCs: An empirical investigation of the role of HRM practices in foreign subsidiaries. Human Resource Management, 48(4), 505530. http://doi.org/10.1002/hrm.20296.

Škare, M., Tomic, D., \& Porada-Rochon, M. (2018). Exploring the Gibson law in CEE countries using a time series approach. E\&M Ekonomie a Management, 11(4), 4-18. http:// doi.org/10.15240/tul/001/2018-4-001.

Stahl, G. K., Pless, N. M., Maak, T., \& Miska, Ch. (2018). Responsible Global Leadership, 363-388. In Global Leadership. Research, Practice, and Development. Edited by Mendenhall, M. E., Osland, J. S., Bird, A., Oddou, G. R., Stevens, M. J., Maznevski, M. L., Stahl, G. K. (2018). New York/London: Routledge.

Syllignakis, M. N., \& Kouretas, G. P. (2011). Dynamic correlation analysis of financial contagion: Evidence from the Central and Eastern European markets. International Review of Economics \& Finance, 20(4), 717732. https://doi.org/10.1016/j.iref.2011.01.006.

Tarique, I., Briscoe, D. R., \& Schuler, R. (2016). International human resource management: Policies and practices for multinational enterprises. London: Routledge.

Thomas, D. C., \& Lazarova, M. B. (2014). Essentials of International Human Resource Management. Managing People Globally. Los Angeles/London: SAGE Publications.
UNCTAD. (2018). Retrieved December 15, 2018, from http://unctad.org/en/Pages/DIAE/ Transnational-Corporations-Statistics.aspx.

VanPool, T., \& Leonard, R. (2011). Quantitative Analysis in Archaeology. Hoboken, $\mathrm{NJ}$ : Wiley-Blackwell.

Vetráková, M., Smerek, L., \& Seková, M. (2017). The importance of human resources management in business practice in Slovakia. Vision 2020: Sustainable Economic development, Innovation Management, and Global Growth. 30th International BusinessInformation-Management-Association Conference, Madrid.

Welch, D., \& Björkman, I. (2015). The place of international human resource management in international business. Management International Review, 55(3), 303-322. http://doi. org/10.1007/s11575-014-0226-3.

prof. Ing. Milota Vetráková, PhD. Matej Bel University in Banská Bystrica Faculty of Economics Department of Tourism and Hospitality Slovakia milota.vetrakova@umb.sk

Mgr. Ing. Lukáš Smerek, PhD. Matej Bel University in Banská Bystrica Faculty of Economics Department of Corporate Economics and Management Slovakia lukas.smerek@umb.sk 


\section{Abstract}

\section{COMPETITIVENESS OF SLOVAK ENTERPRISES IN CENTRAL AND EASTERN EUROPEAN REGION}

\section{Milota Vetráková, Lukáš Smerek}

The position of Slovakia in the region of Central and Eastern Europe is analysed in this paper. In examining this, we build on the axiom of the dominant position of multinational companies, which are an important part of international business, international economy and trade. They affect global competitiveness on international markets, including the quality of life of people. The paper explains how globalization contributes to increasing Slovakia's competitiveness in CEE, how human resources management practices support successful companies located in the TOP 500 CEE ranking and what the management system prevails. We rely on the theoretical knowledge of wellknown experts in human resources management in the international environment, confronting their theoretical knowledge with our own research conducted by structured interviews with human resources managers of selected companies in Slovakia placed in the TOP 500 CEE ranking. The purpose of these efforts is to both theoretically and practically support the importance of human resources management in achieving positive business results on an international scale. By applying mathematical-statistical methods, we have found that there is a statistically significant difference between enterprises in which different approaches are applied in relation to the application of convergence or divergence. We have found strong dependence, confirming the assumption that the convergence or divergence is the result of the company's approach to HRM activities. To verify the assumption of the difference in performance of HRM processes in MNCs and local enterprises, we used additional tests. The results confirmed the presumption that the performance of HRM processes in MNCs and local enterprises is different in more than half of the processes.

Keywords: Multinational company, international human resource management, CEE region, convergence, divergence.

JEL Classification: F23, M12, M16.

DOI: 10.15240/tul/001/2019-4-003. 